\title{
A Pilgrim's Additions. Traces of Pilgrimage in the Belles Heures of Jean de Berry
}

\author{
Hanneke van Asperen \\ Radboud University, Nijmegen, Netherlands
}

The names of Jean de Berry and the Limbourg brothers are inextricably bound up with the Belles Heures. After all, both the commissioner and the makers left their personal mark on the manuscript. Because the names of the talented brothers and the bibliophile duke arouse everyone's curiosity and admiration, scholars pay less attention to the afterlife of the manuscript book of hours. The book must have been read and admired, after the duke passed away and the book changed hands. Notably however, in the manuscript itself there are no indications of its subsequent owners. Actually, very few traces of wear and tear inform us of the way the manuscript was used after it left the residence of the duke of Berry. Until the reader reaches f. 2 I. On this blank folio without any text or miniature, there are two imprints of small pilgrims' souvenirs.

The blank page with the impressions of the badges is the starting point of this contribution. From studying comparable imprints in books, it is possible to deduce when the badges must have been sewn in. More fascinating than the exact moment the badges were added to the book, is the question why. What was the motivation? Did the owner at the time look at the contents of the codex when he applied the badges or is their location arbitrary? In other words, is there a direct relationship between the badges and the book? As a comparison with a book of hours of duke Philip the Good of Burgundy will show, the Belles Heures are not an isolated example of a devotional manuscript with traces of pilgrimage souvenirs. The owners firmly embedded the badges (and so their pilgrimage) into their religious life. The location of the badges sheds some light on the reasons of the pilgrim to add the badges and consequently on the way the book of hours and its pictures or picture cycles were conceived. 


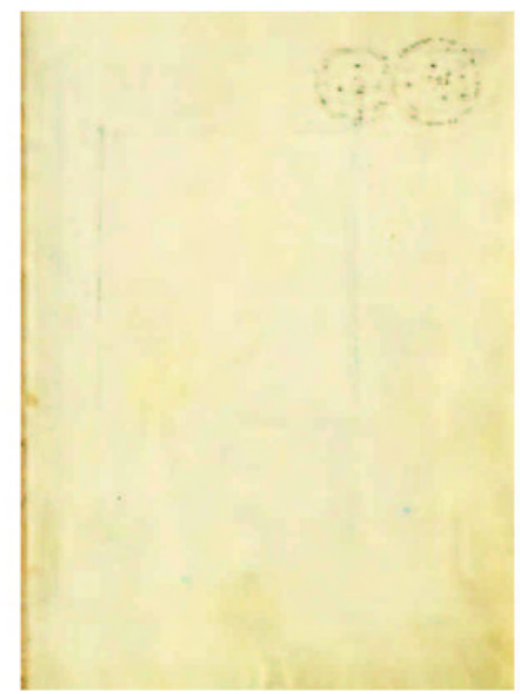

I. Imprints of two pilgrim's badges, f. 2Ir. New York, Metropolitan Museum of Art, The Cloisters Collection, acc.no. 54.I.I.

\section{The Scholarly Literature}

The imprints of the badges appear in the upper right hand corner of $f_{\text {. }} 2 \mathrm{I}$ (illus. I). This is a blank page without text or miniature, without lining or marginal decoration. The page is part of a bifolium, together with f. 29, added to protect the pages containing the gospel lessons (ff. 22-28). The imprints are faint, they show very few details. The offets just give an indication of the outer edge and some of the protruding parts of the badges. ${ }^{\mathrm{I}}$ The two medals must have measured about 28 and 3I mm, but their imagery remains a mystery.

In an article in the Gatherings in honor of Dorothy Miner, John Plummer already mentions the circular offsets. ${ }^{2}$ In his contribution, Plummer discusses the missing miniature that once preceded the gospel of Saint John. When he depicts the verso of $\mathrm{f} .2 \mathrm{I}$ to show the offset of the missing miniature, he tells us

I At this point, I would like to thank Margaret Lawson who was kind enough to observe ff. 20 and $2 \mathrm{I}$ in detail for any traces that the badges might have left. Unfortunately, the traces of the offset material are too faint to establish what metal the badges were made of. Margaret Lawson informed me that the parchment itself has offset pigments and dirt overall. This makes it difficult to obtain an accurate measure of the parchment as a background reading.

2 John Plummer, 'A blank page in the Belles Heures', in: Gatherings in honor of Dorothy E. Miner, ed. Ursula E. McCracken (Baltimore 1974), p. 197. 
to disregard 'the two dark rings in the upper left and the dark spots they encircle, for these are stains showing through from the preceding page'. For Plummer's research on the miniature of Saint John, a further identification of the offsets is not relevant.

It is not until recently that scholarly attention has turned towards these traces of pilgrimage souvenirs. Since John Plummer described the folio in the Belles Heures, some scholars have dedicated themselves to the custom of attaching badges to manuscripts. Kurt Köster, for example, describes several manuscripts with badges and offsets in two articles that were published in 1965 and 1979 (seven manuscripts in total). ${ }^{3}$ In 1998 , Denis Bruna has added a few manuscripts and one incunable with badges and devotional pictures in them (nine manuscripts). ${ }^{4}$ These publications with the description of sixteen different manuscripts are a perfect base for further study of badges and imprints.

The books with badges are almost exclusively books of hours and some prayer-books. Apparently, pilgrims liked adding their souvenirs to devotional texts. Furthermore, almost all manuscripts are books of everyday use. They show many traces of wear and tear. Finally, traces of badges in manuscripts are not unique and, as was to be expected, many manuscripts with traces of badges can be added to the rough inventory of Köster and Bruna. ${ }^{5}$

Slowly, scholars are starting to recognize the imprints that adorn many devotional books, as illustrated by the recent publications on the Belles Heures. In the volume that accompanies the new facsimile of the Belles Heures (2004), Eberhard König mentions the imprints as well, identifying them as pilgrims' badges. 'Jean de Berry selbst wird das Buch eine gewisse Zeitlang als Gebetbuch benutzt haben. Die auffälligste Spur fromme Gebrauchs mag erklären, warum ausgerechnet eine Bildervita der heiligen Katharina (ff. I5-20) als

3 Kurt Köster, 'Religiöse Medaillen und Wallfahrts-Devotionalien in der flämischen Buchmalerei des 15 . und frühen I6. Jhs. Zur Kenntnis gemalter und wirklicher Kollektionen in spätmittelalterlichen Gebetbüchern', in: Buch und Welt. Gustav Hofmann zum 65. Geburtstag dargebracht, eds. H. Striedl \& J. Wieder (Wiesbaden 1965), pp. 459-504 and Kurt Köster, 'Kollektionen metallener Wallfahrts-Devotionalien und kleiner Andachtsbilder eingenäht in spätmittelalterliche Gebetbuch-Handschriften', in: Erlesenes aus der Welt des Buches. Gedanke, Betrachtungen, Forschungen, ed. Bertram Haller (Wiesbaden 1979), Pp. 77-130.

4 Denis Bruna, 'Témoins de dévotions dans les livres d'heures a la fin du Moyen Age', in: Revue Mabillon, 9, t. 70 (1998), pp. I27-6I.

5 See for example A.M. Koldeweij, 'Pelgrimsinsignes in het getijdenboek "D'Oiselet", in: Heilig en Profaan. 100o Laatmiddeleeuwse Insignes wit de collectie H.J.E. van Beuningen, eds. H.J.E. van Beuningen \& A.M. Koldeweij (Cothen 1993), pp. 46-8, and Brian W. Spencer, Medieval finds from excavations in London, VII: Pilgrim souvenirs and secular badges (Southampton 1998), p. 20, illus. Io. 
Erkennungszeichen dienen konnte. Direkt im Anschluß daran erkennt man auf fol. 2I zwei runde Abdrucke; sie stammen offenbar von Abzeichen, wie sie Pilger heimbrachten'. ${ }^{6}$ König did not just identify the impressions, he also recognized their value in understanding the devotional usage of the book. His suggestion that Jean de Berry himself might have added the pilgrimage souvenirs to the book, needs some further investigation. The fact that the duke commissioned the book does not necessarily imply that he was the only one to ever use it. Yolande of Aragon and the owners after her could have taken up the manuscript as well, even applying it for their devotions.

\section{The Practice to Attach Badges to Books}

The practice to add badges to devotional books only seems to have become popular during the second half of the fifteenth century. The origins can be connected with the development of a new type of badge: the punched medal. From the twelfth century onwards, pilgrims' badges for the most part were cast. The liquid metal, usually pewter, was poured into a mould of slate or sandstone. During the fifteenth-century, a new technique to make pilgrimage souvenirs came into use besides the usual casting. An image was punched into a wafer-thin sheet of metal with a die of iron leaving a negative imprint on the back of the badge. Because the metal is so flimsy, the badge is light, with a tendency to break or tear. This technique was used mainly for badges of a copper alloy or silver, more precious materials than pewter. The silver badges could even be gilded, for a more demanding clientele.

The stamped badges differed fundamentally from their cast relatives. They are usually very small, about $20-30 \mathrm{~mm}$ in diameter, and extremely light (they generally weigh less than one gram). The images were sometimes provided with punched holes, so that the objects could be attached to a background with needle and thread. The different characteristics gave rise to new applications: the badges could be hung on a rosary or sewn onto the pages of a manuscript. The light badges were extremely suitable for an attachment to the parchment, because they didn't tear the page.

The technique was used for the production of clothing ornaments. During the reign of Philip the Bold (1342-I404) for example, courtiers wore trinkets on their clothing that were stamped out of thin pieces of gold and silver. The technique of these ornaments corresponds to the stamped badges, even though

6 Eberhard König, Die Belles Heures des Duc de Berry. Sternstunden der Buchkunst (Luzern 2004), p. I3. 
the objects had another usage. For workers in precious metals, it was a small step to translate this familiar technique to pilgrims' badges that could be worn on clothing as well. The stamped souvenirs however were only produced on a large scale from the second half of the fifteenth century. ${ }^{7}$ Most of the books with (traces of) badges, published by Köster and Bruna, date from the end of the fifteenth century or beginning of the sixteenth century. The practice to add pilgrimage souvenirs to devotional books apparently became popular during the final decades of the fifteenth century, during the final years of the reign of duke Philip the Good of Burgundy (who died in 1467) and after. During this period, stamped medals were available at every pilgrimage site, often as an expensive(-looking) alternative for the pewter badges.

In different books of prayer that once belonged to Philip the Good, imprints of badges show up. ${ }^{8}$ In the Grandes Heures of Philip the Good (Brussels, Bibliothèque Royale de Belgique, MS in 035-37 and Cambridge, Fitzwilliam Museum, MS III-I954), more than fourty-six metal badges once adorned the pages. ${ }^{9}$ The book originally belonged to Philip the Bold, but the badges were not attached to the parchment until after $\mathrm{I} 440$, when the memoriae were added to the manuscript. ${ }^{10}$ Other badges accompany prayers that were written by Jean Miélot; these prayer texts were not added to the manuscript until I45I (ff. $7 \mathrm{r}$. and $87 \mathrm{v}$.) providing a terminus post quem. ${ }^{\text {II }}$

7 Kurt Köster, 'Mittelalterliche Pilgerzeichen und Wallfahrtsdevotionalien', in: Rhein und Maas. Kunst und Kultur 800-I400 (Cologne I972), pp. I46-60 (p. I48) and Brian W. Spencer, op. cit. (n. 5), p. 20.

8 Brussels, Bibliothèque Royale, MS II 035-37, Cambridge, Fitzwilliam, MS III-1954 and Vienna, Österreichische Nationalbibliothek, MS ı80o. See Köster, art. cit. (n. 3: 1965), Köster, art. cit. (n. 3: 1979) and Bruna, art. cit. (n. 4), P. I46, no. I.

9 On the badges in the Grandes Heures, see Köster, art. cit. (n. 3: 1979), pp. 87-IO3 and Bruna, art. cit. (n. 4), p. I46. The manuscript in Cambridge contained 25 badges, the book in Brussels $2 \mathrm{I}$.

Io Cambridge, Fitzwilliam Museum, MS III-I954, ff. 226-75. Alain Arnould \& Jean Michel Massing, Splendours of Flanders (Cambridge 1993), p. 144. On the complex history of the manuscript hours, see Anne Hagiopan van Buren, 'Dreux Jehan and the Grandes Heures of Philip the Bold', in: Als ich can, eds. Bert Cardon, Jan Van der Stock et al. (Paris 2002), Pp. 1377-4I4 and Bernard Bousmanne, Céline Van Hoorebeeck \& Alain Arnould, La Librairie des Ducs de Bourgogne. Manuscrits conservés à la Bibliothèque Royale de Belgique, vol. I: Textes liturgiques, ascétiques, théologiques, philosophiques et moraux (Turnhout 2000), pp. 264-72.

II Claudine Lemaire identified the writer of the prayer to the Virgin on ff. 87v-90or. as Jean Miélot. Lemaire identified the writer of the four prayers against the temptation of the flesh that were added to the miniature of the Apocalyptic Virgin (f. 7r.), as 'Main B'. Bousmanne, Hoorebeeck, Arnould, op. cit. (n. 10), p. 268. According to Anne Hagiopan van Buren, Jean Miélot wrote the prayers against the temptations of the flesh as well. Hagiopan van Buren, art.cit. (n. Io), p. 1388. 
The badges must have been attached to the parchment during the second half of the fifteenth century or shortly after, perhaps by Philip the Good himself who certainly had cause and opportunity to purchase the souvenirs. In fact, Philip the Good was a passionate collector of pilgrimage souvenirs. ${ }^{\mathrm{I2}}$ Philip the Good certainly used the book on a regular basis. In the commission to Dreux Jean of I45I, the book is called 'les grandes heures cotidienne', paraphrased 'the large hours for daily usage'. ${ }^{13}$ The omission of the book from the list of objects in his library that was made up after his death, could mean that the book was kept in the private chapel of the duke in Dijon that was left out of this inventory. ${ }^{\mathrm{I}}$ Philip the Good had the means and the oppurtunity to add the badges to the book. Because the owner of the book after the death of the duke is uncertain, it is tempting to point to Philip as the pilgrim to collect the badges. However, the badges could have been added after Philip's death as well. The practice to attach the souvenirs to pages of a manuscript prayer book remained in use until into the sixteenth century.

The badges in the Belles Heures must have been added during the second half of the fifteenth century or the beginning of the sixteenth century as well, when the mass production of the stamped badges and the practice to add them to books were well established. Unfortunately, the identity of the owner at the time remains a mystery. After the death of the duke in I4I6, the manuscript prayer book was sold. It remained within the hands of family. It was purchased from the estate of the duke by Yolande of Aragon (I383-I443) who was a great-niece of Jean de Berry, and a niece by matrimonial bond..$^{\text {is }}$ She wed a nephew of the duke, Louis II of Anjou. They had several children, among who Marie (1404-63), the future wife of Charles VII who was crowned king of France in I429. Another one of their children was René of Anjou (I408-80), who became known as René the Good, titular king of Naples, Jerusalem and Aragon. Yolande died in I443. The book could have been part of her library for

I2 On the purchase of badges by Philip the Good, see Comte De Laborde, Les ducs de Bourgogne. Etudes sur les Lettres, les Arts et l'Industrie pendant le XVe siècle et plus particulièrement dans les Pays-Bas et le Duché de Bourgogne, 3 vols. (Paris I849-52) and De la Fons-Mélicoq, 'Documents pour servir a l'histoire des médailles', in: Revue de la Numismatique Belge, 24 (I868), pp. 75-8I.

I3 Hagiopan van Buren, art. cit. (n. Io), p. 138I, n. 28 and Bousmanne, Hoorebeeck, Arnould, op. cit. (n, I0), p. 27 I.

I4 Bousmanne, Hoorebeeck, Arnould, op. cit. (n. Io), p. 27I.

I5 Jean Lebourne, secretary and guardian of the estate, took the book into his custody when Jean de Berry died. The then estimated value was 875 livres tournois. Yolande bought it for 300 livres. König, op. cit. (n. 6), p. 13, and Paul Durrieu, 'Les "Belles Heures" de Jean de France Duc de Berry', in: Gazette des Beaux-Arts, 48, pér. 3, tome 35 (1906), pp. 265-92 (p. 267). 
some time. Whether the manuscript book stayed in the possession of her family, perhaps one of her children, is uncertain.

Only in I880, the manuscript resurfaced as part of the collection of the French noble family D'Ailly, perhaps owned - according to the Metropolitan Museum - by the baron d'Ailly, when it was acquired by baron Edmond de Rothschild. ${ }^{16}$ In all probability, the manuscript stayed within the hands of French nobility after it left the residence of Yolande of Aragon.

\section{The Motivation of the Pilgrim}

The person to add the badges to a book had several reasons to do so. Of course, the manuscript protected the fragile badge from loss and damage. This way, the memory of the pilgrimage was preserved. Pilgrimage souvenirs were tangible relics of a devotional journey and, as such, a suitable addition to a book containing devotional texts for personal use.

Within the context of the book, the owner could vary the locations of the badges, dependant on the available locations and the personal preferences of the book owner. The owner of the Belles Heures did not apply the badges to a fly leaf of the manuscript hours. The prints appear on f. 2I. These imprints are offsets of the front side of the badges. Sewing holes are missing and the characteristics of the imprints also indicate that the badges must have been attached to the preceding page. On $\mathrm{f} .20$ however, no traces of badges are visible at all, and no sewing-holes. The page shows only a few slight dimples in the top corner, not nearly enough to establish the presence of badges on that page. This means, there must have been another support for the badges - between the current ff. 20 and $2 \mathrm{I}-$ that is now missing. The collation affirms this assumption. Presumably, f. $\mathrm{I}_{4}$ - now a singleton - was once part of a bifolium, protecting the quire with the picture cycle of Saint Catherine, as the blank bifolium around the gospel lessons. ${ }^{17}$ Apparently, the two badges were part of the miniature cycle of Saint Catherine before they were removed together with their original support.

I6 Cristopher De Hamel, The Rothschilds and their Collections of Illuminated Manuscripts (London 2005), p. 26. See also Léopold Delisle, Mélanges de palégraphie et bibliographie (Paris I880), pp. 283-93 and Durrieu, op. cit. (n. I5), p. 267.

17 For the collation, see Plummer, art. cit. (n. 2), p. 194 and the revised table of the breakdown of the quires in The Belles Heures, illus. 28 in the contribution of Margaret Lawson to this volume. 


\section{The Image of Mary in the Grandes Heures}

The Grandes Heures, once in the possession of duke Philip the Good, provides another example of badges that were added to an illumination. The then owner of this book of hours added dozens of badges to the manuscript. The pilgrim-owner carefully studied the contents of the book before sewing the objects to the pages. For example, a badge of Saint Sebastian accompanies a prayer to Saint Sebastian (f. $226 \mathrm{v}$.), a badge of Nicholas is set alongside a memoria to that saint (f. $246 \mathrm{v}$.), etc. ${ }^{18}$ Five badges, undoubtedly with a depiction of Mary, accompany prayers to the Virgin (f. 7 r.). Apparently, the badges provided the devotee with a suitable image when he recited the text at hand. One time, the owner of the Grandes Heures selected a miniature as a suitable location (illus. 2).

The miniature of the Virgin and Child, obviously trimmed along the sides, probably used to be part of a larger manuscript or circulated as a single leaf before it became part of the Grandes Heures. For the major part, the imprints of the badges remain within the outlines of the page indicating the objects were added after the miniature joined the Grandes Heures, probably in I45I when the book was subdivided and rebound. ${ }^{\text {I9 }}$ The objects partially even overlap the precious picture. Judging from the few readible imprints, the badges did not (just) show images of Mary, they depict other saints, such as Adrian who was venerated in Geraardsbergen. ${ }^{20}$ The badges around the miniature apparently comprised various figures of saints and relics.

The answer to the question why the badges were added to the miniature of Mary lies in the image itself. In the Grandes Heures, the Virgin is depicted on the crescent. This imagery is derived from the Apocalypse (I2:I): 'And a great sign appeared in heaven: A woman clothed with the sun, and the moon under her feet, and on her head a crown of twelve stars.' Even though the figure is not 'clothed with the sun', the image follows the general description of the Bible verse. The crescent below Mary is surrounded by angels and two of them place the crown studded with stars on her head. The illuminator combined the iconographical theme of the Apocalyptic Virgin with that of the Virgo Lactans, meaning the Virgin is suckling the Child that is lying in her arms.

I8 Köster, art. cit. (n. 3: 1979), Pp. 96-IO3.

I9 The miniature of the Apocalyptic Virgin, even though it is obviously older than the prayers that go with it, was added to the manuscript at the same time, around 1450. Hagiopan van Buren, art. cit. (n. Io), p. 1384 .

20 Köster, art. cit. (n. 3: 1979), pp. 88-92. 


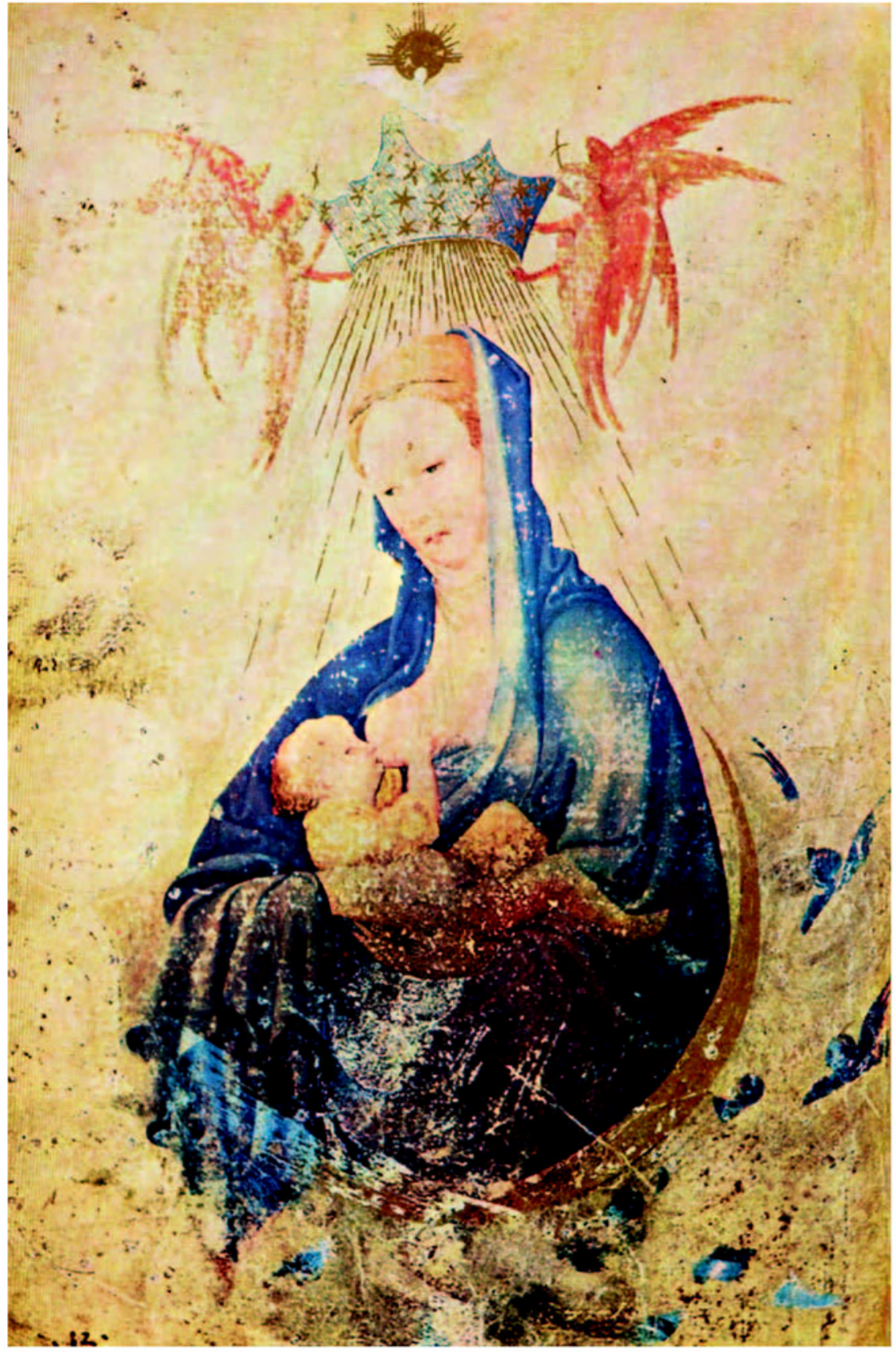

2. Master of the Breviary of John the Fearless, miniature of the Apocalyptic Virgin, Grandes Heures, f. 6v. Brussels, Bilbiothèque Royale de Belgique, MS I I 035-37. 
The miniature used to be attributed to the Limbourg brothers. ${ }^{2 I}$ Today, the illuminator from the surroundings of the brothers-illuminators is usually referred to as the Master of the Breviary of John the Fearless. ${ }^{22}$ The former confusion with the Limbourgs is not entirely surprising, since there are many resemblances with Limbourg miniatures, especially with an illumination from the Belles Heures (illus. 3). Similarities do not just appear in small details such as the half-closed eyes, the drooping corners of the mouth and the intimate relationship between mother and child; the Virgin is depicted in an almost identical fashion. She is wearing a similar blue garment that partly covers her wavy blond hair. Draperies and folds carefully cover up the fact that the lower part of Mary's body is missing. The Virgin holds the child close to her chest and even though she is not suckling it, the position of the child and that of her hands is analogous. In both images, Seraphim - the highest in the hierarchy of angels - are holding up a crown. The six-winged angels in the Belles Heures however are not crowning the Virgin, as they are in the Grandes Heures; they crown God the father. Seraphim usually appear around the heavenly throne. The Master of the Breviary of John the Fearless probably copied the angelic figures from the Limbourg illumination without adjusting their place in the hierarchy to their changed duties.

Of course, there are many differences between the miniatures of Mary, the most eye-catching being the many figures that surround the Virgin and Child in the Belles Heures. Mary is depicted in the company of saints and the Trinity. God appears in the upper part of the miniature, with John the Apostle and John the Baptist on both sides, and the dove of the Holy Spirit below, completing the Trinity. Below them is a multitude of saints. The major part of the figures is not even recognizable as they are partially obscured by the large aureoles. Immediately flanking the Virgin are undoubtedly the Saints Paul and Peter. Paul carries the sword, but Peter lacks his attribute. He is recognizable because of his robe, bolding head, short grey beard and his position opposite to Paul. In front of Mary looking up to her are popular female saints such as Catherine, Dorothy, Margaret, Barbara and Apollonia with the pincers. All of the figures face the Virgin and Child and some of them fold their hands in prayer, as if the figures of the Virgin and Child are some sort of apparition.

2I Fréderic Lyna, 'Un livre de prières inconnu de Philippe le Hardi (Bruxelles, MS II035-37)', in: Mélanges Hulin de Loo (Brussels, etc. 193I), pp. 249-59 (pp. 254-9).

22 Hagiopan van Buren, art. cit. (n. IO), p. I384, Bousmanne, Hoorebeeck, Arnould, op. cit. (n. Io), p. 270 and Millard Meiss, French painting in the time of Jean de Berry. The Limbourgs and their contemporaries (New York 1974), pp. 236-7. 


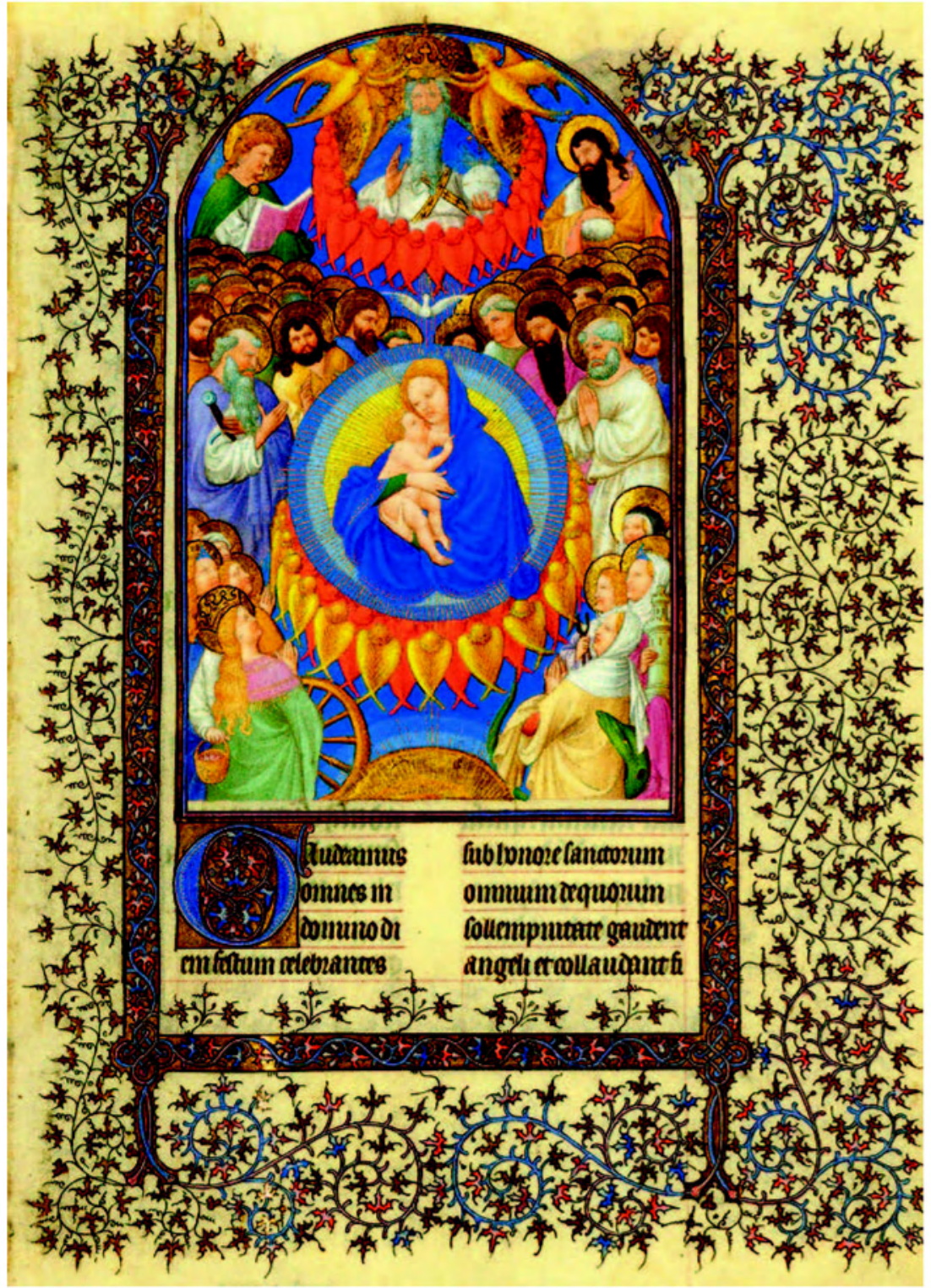

3. Limbourg brothers, miniature of the Virgin surrounded by saints, Belles Heures, f. 2r 8r. New York, Metropolitan Museum of Art, The Cloisters Collection, acc. no. 54.I.I. 
The spatial organization of the saints encircling Mary accentuates this idea of a vision. On the side of the onlooker, the saints open up the circle to impart the viewer to the vision of heaven.

The Master of the Breviary of John the Fearless left the saints out of his version of the miniature, for he was depicting a vision of the Apocalyptic Virgin, rather than a vision of Paradise. The saints were only added at a later stage when the owner attached the badges to the book. In applying the badges, the owner of the book changed the iconography of the image drasticly, partially obscuring the angels around the crescent. He pictured Mary in the heavenly realm surrounded by the community of saints, not unlike the miniature in the Belles Heures. Perhaps, the owner actually knew the image from the book of hours that once belonged to Jean de Berry. More likely, the owner knew comparable images of Mary in the company of saints.

With the badges, the owner added a personal note to the miniature of Mary. After all, the saints that surround Mary in the Grandes Heures have a special meaning to the owner of the manuscript. He probably visited a lot of the cult sites and gave his offerings to the saints that are represented in the manuscript prayer book through their images. Conceivably, the devotee hoped for a special treatment from the saints whom he had shown his deference. In adding the badges to the miniature of Mary, he did not just paint an arbitrary picture of the heavenly realm; he created a desirable image of heaven where the saints would be well-disposed towards him.

\section{The Picture Cycle of Saint Catherine in the Belles Heures}

The owner of the Belles Heures added similar stamped badges to his book of hours, also to a miniature. There are several differences. The subject of the illumination was not Mary, but Saint Catherine of Alexandria. Moreover, the pilgrim-owner did not add the badges to one miniature in particular. The badges follow a cycle of miniatures depicting the life of the saint. The reasons to add badges to the Belles Heures were different.

In the manuscript as a whole, pilgrimage plays a special role. The themes of journey and pilgrimage recur several times. Some saints are depicted as pilgrims, for example Saint Jerome visiting the Holy Sepulchre in Jerusalem (f. I85v.) and Saint James (f. I6ov.). In the latter miniature, the illuminator did not just represent the apostle, like the miniatures of the other saints and angels. Instead, he painted the interior of a chapel or church by placing the saint upon an altar. In front of the altar, two pilgrims kneel down to venerate the statue 
of the apostle. In adding the pilgrims, the illuminator created a view of a pilgrimage site of Saint James. Eberhard König recognized a pilgrim in one of the four figures kneeling in front of the golden cross. ${ }^{23}$ Also the texts refer to travels. The final text of the manuscript hours is a prayer to read before going on a journey (f. 223v.).

The badges were once attached to a blank folio after the picture cycle of Saint Catherine, more specifically following the miniature with the translation of her relics to Mount Sinai (illus. 4). One reason for the owner to attach the badges to this folio, could have been the connection of this image of Catherine with pilgrimage. The miniature does not just show the miraculous translation, it also depicts the monastery where the relics were kept after their discovery. In the foreground, a group of pilgrims approach with the intention to venerate and touch the remains of the saint.

The pilgrims and the monastery building formed part of the miniature from the outset. The text below the miniature does not mention the monastery, but it relates of the oil that flows from Catherine's body healing the sick. Like the other captions in the miniature cycle, it was taken from the Golden Legend. 24 This miraculous oil that was widely known, attracted many pilgrims from all over the Christian world to the site of the relics of Saint Catherine on Mount Sinai. Possibly, the Limbourgs added the monastery to illustrate the passage on the miraculous oil. Perhaps, the brothers met the demands of the duke when they added the building. As Millard Meiss already stated, 'the French court felt a close connection to the convent'. ${ }^{25}$ Charles VI donated a precious chalice in I4II with the royal fleurs-de-lis of France. Both Jean de Berry and his brother Charles V kept amongst their relics some splinters of the tomb of the saint. Jean's son-in-law Philip of Artois (1358-97) actually visited the monastery of Saint Catherine in $\mathbf{1 3} 89$ after his emprisonment in Cairo. ${ }^{26}$

The stamp of the duke's personality also shines through in other parts of the manuscript, especially in places where the Limbourgs depicted existing sites and buildings, such as the Grande Chartreuse in the Life of Bruno (illus. 5). The miniature shows the mother convent that was founded by the saint. The duke was an important benefactor of the carthusian monastery which is probably

23 König, op. cit. (n. 6), p. II4.

24 Jacobus de Voragine. The Golden Legend. Readings on the Saints, vol. II, ed. and transl. William Granger Ryan (Princeton, N.J. 1992) p. 339.

25 Millard Meiss \& Elizabeth H. Beatson, De Belles Heures van Jean, Duc de Berry (Utrecht, etc. 1975), p. 24.

26 König, op. cit. (n. 6), p. 6I and Millard, Beatson, op. cit. (n. 25), no. 24. 


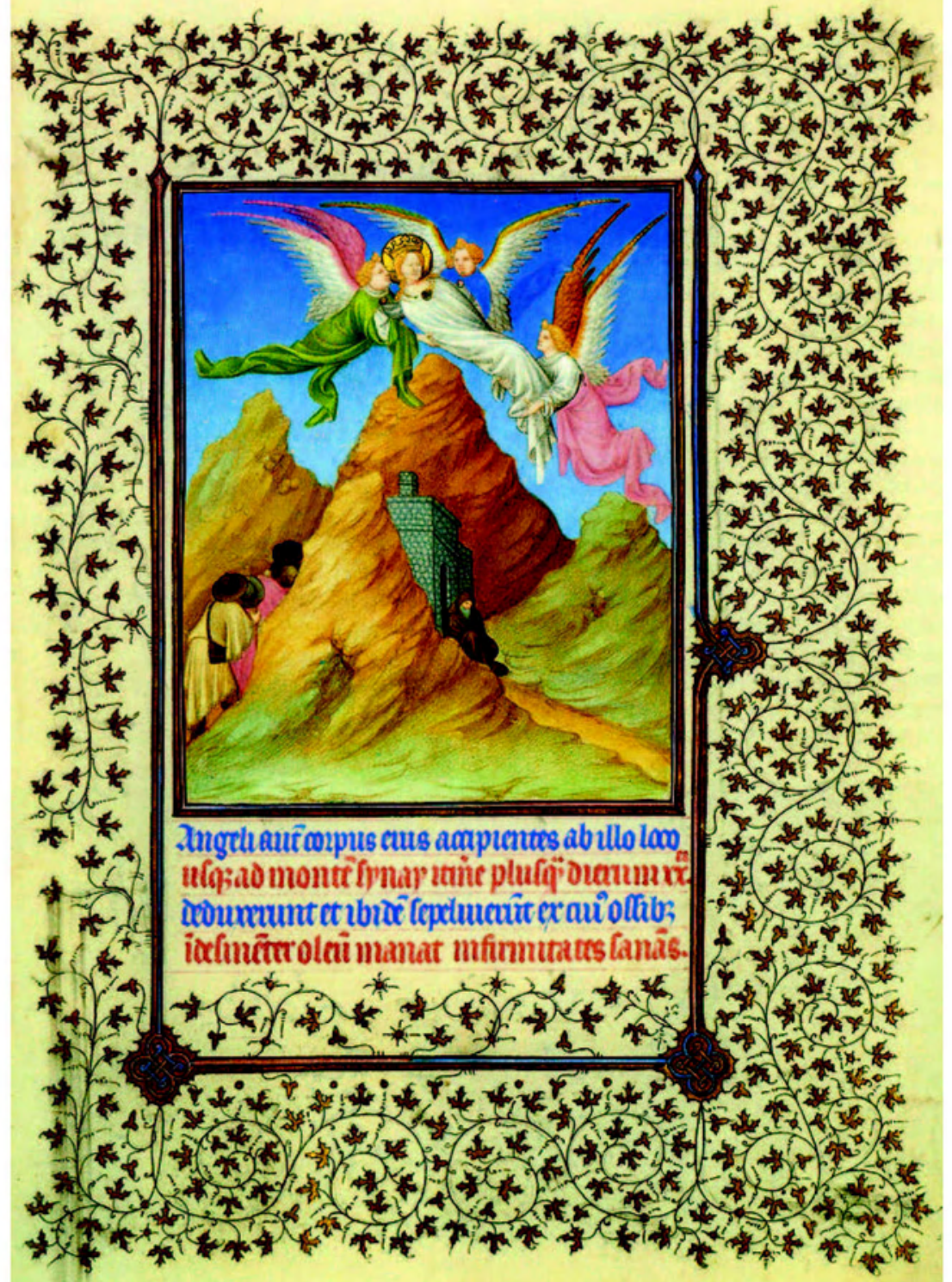

4. Limbourg brothers, miniature with the translation of Catherine's body to Mount Sinai, Belles Heures, f. 2or. New York, Metropolitan Museum of Art, The Cloisters Collection, acc.no. 54.I.I. 


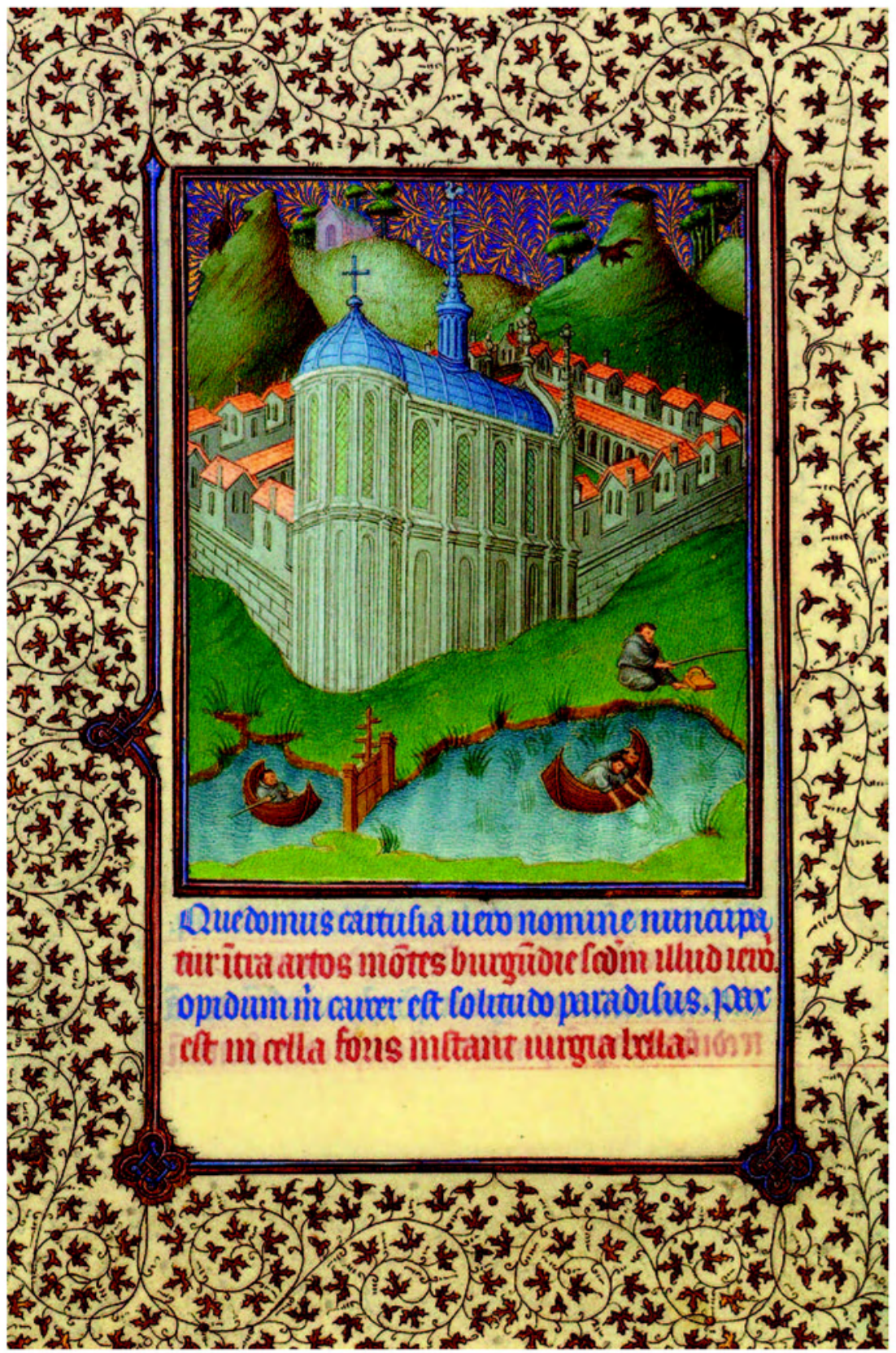

5. Limbourg brothers, miniature with the Grande Chartreuse, Belles Heures, f. 97v. New York, Metropolitan Museum of Art, The Cloisters Collection, acc.no. 54.I.I. 
why it takes up such an important place in the picture cycle and why it is depicted in such detail. The monastery of Saint Catherine also had personal meaning for Jean de Berry. Therefore, the building on Mount Sinai could have been a special request of the duke as well.

Commissioned or not, the monastery of Saint Catherine was clearly recognizable to the beholder. The miniature shows some of the basic elements of the monastery: the almost square groundplan and the thick walls with few windows. In fifteenth-century journals, pilgrims describe the closed exterior of the cloister that is so impressive. Joos van Ghistele for example, who undertook a pilgrimage to the Holy Land in I480's, pictures the exterior of the monastery as 'a square place with high strong thick walls with only a couple of windows, and it has only two doors that are not very big..$^{27}$

The Limbourg brothers did not just depict the building as it appeared to contemporary pilgrims, they also depicted the characteristics of its surroundings with the bare and extremely steep mountains (illus. 6). 'The monastery', says Anselm Adornes who visited the cult site in I470-7I, 'is situated at the foot of Mount Sinai amidst mountains at the extremity of a narrow plane; it also finds itself surrounded on three sides by very large mountains. ${ }^{28}$ In fact, the mountains around the monastery are so steep, reports another pilgrim, that if a person should stand in front of the building and look up, it would seem like the mountains round it would fall on it. ${ }^{29}$

The illuminators also depicted the pilgrimage route along dangerous passage ways. Journals describe this route, the only way to reach the cloister, relating how the pilgrims had to cross a narrow pass in the mountain, until they reached a plane - surrounded by the above-mentioned high mountains where they would finally descry the monastery. The pilgrims in the miniature are just entering such a gorge on their long way to the cult site.

The Limbourg brothers must have known and used drawings and other models of the building and its surroundings when they painted the miniature. Still, the image was never intended to be an actual portrait of the monastery with a clear depiction of the different parts of the building. It does not show every detail. The edifice is relatively small in comparison to the Grande Chartreuse for example (illus. 4 and 5). A large part of the building remains hidden behind a large mountain in the foreground. The Limbourgs rather depicted the essence of the site. They accentuated the austere exterior and the desolated

27 Ambrosius Zeebout, Tvoyage van Mher Joos van Ghistele (Hilversum 1998), p. 242.

28 Anselme Adornes, Itinéraire d'Anselme Adorno en Terre Sainte (I470-I47I), eds. Jacques Heers \& Georgette de Groer (Paris 1978), p. 225.

29 Malcolm Letts, The pilgrimage of Arnold von Harffknight (Wiesbaden 1967), p. I40. 


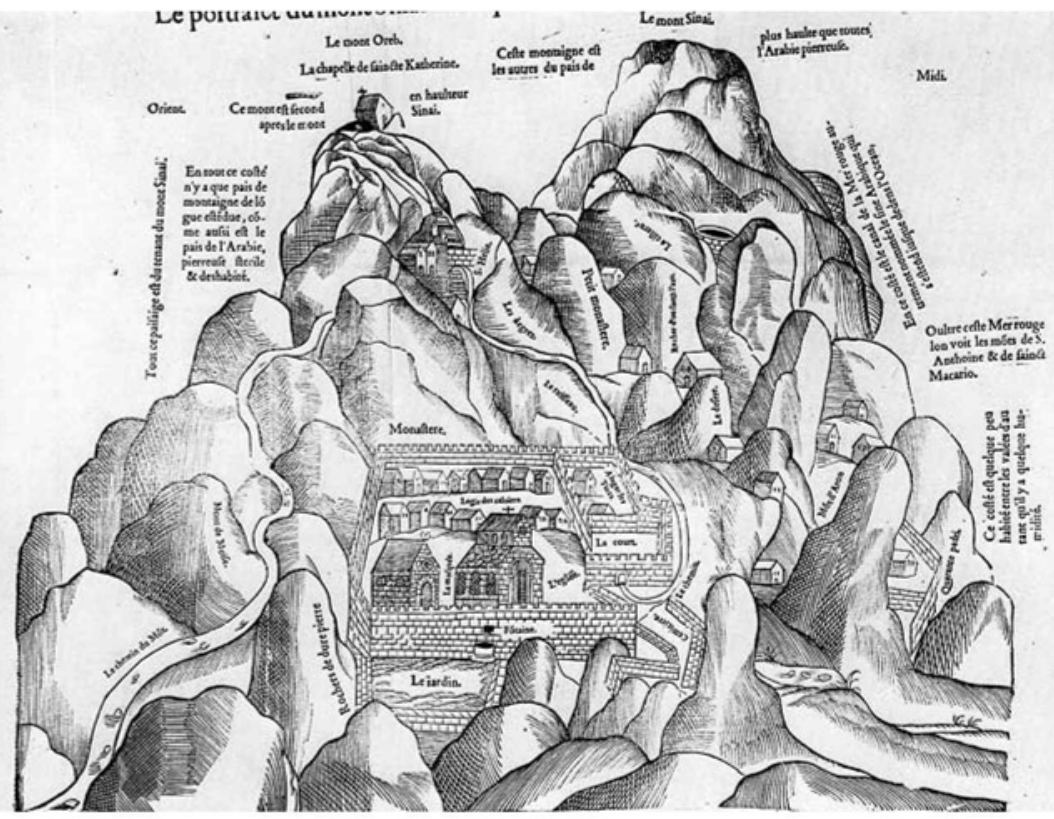

6. Le portrait du Mont Sinai, print from the edition Les observations de plusieurs singularitez, I555. From: Mahfouz Labib, Pèlerins et voyageurs au Mont Sinaï (Caire I96I), pl. VI.

atmosphere of the monastery that is described in contemporary pilgrim's journals. The miniature shows its desolateness and secludedness instead of its splendor and grandeur. By keeping the monastery small and partially disguised by the mountains, the Limbourg brothers stressed the inaccessabilty of the building and the toughness of the pilgrimage route. The object of the miniature is not topographical accuracy, but the labour of pilgrimage.

Most of the time, scholars stress the novelty and the extravagance of the elaborate picture cycles with minimal text in the Belles Heures. Undoubtedly, the duke and later owners enjoyed their beauty. This doesn't alter the fact that the cycle has a devotional value as well. The picture cycle presents Catherine as an exempla, a role model for a pious life. The cycle gives the viewer the opportunity to follow Catherine's example and contemplate the virtues of the saint by studying the events that leaded up to her death. Pilgrims who visited the monastery on Mount Sinai usually came from the city of Alexandria where they visited the locations where Catherine lived, where she was held prisoner, tortured and eventually beheaded. When the pilgrims left for Mount Sinai they actually followed the path that Catherine covered when the angels moved 
her body to Mount Sinai. The devotee, looking at the picture cycle, could contemplate the same events of Catherine's Life and Passion leading up to the translation of her relics.

In the miniature cycle, the physical pilgrimage and the contemplations of the devotee are intertwined. Both ways lead to the same high point: Mount Sinai. The final miniature gives the pious beholder the opportunity to join in his mind the group of pilgrims moving towards the monastery with the relics, in order to venerate Saint Catherine. Pilgrimage obviously plays an essential role in the picture cycle. The pilgrims in the last picture are not just another life-like detail, that makes the work of the Limbourg brothers so pleasing. By adding the pilgrims and the monastery, the illuminators accentuated the theme of pilgrimage, linking the spiritual contemplations on the Life and Passion of Saint Catherine with the physical pilgrimage to Mount Sinai.

\section{Badges of Saint Catherine}

The later owner elaborated on the element of pilgrimage by the addition of badges. It is tempting to insinuate here that the pilgrims' badges must have originated from a cult site of Saint Catherine, Mount Sinai even. Pilgrims could buy souvenirs there. At first, this were mainly small flasks with healing oil that came from the relics of Catherine, mentioned in the caption of the miniature. Later, pilgrims could obtain pieces of silk that had been in contact with the relics. ${ }^{30}$ Many travellers brought their own rosaries, jewelry, and crosses with the same purpose, to touch the relics hoping that some of the miraculous powers were transferred to the objects. ${ }^{31}$ Other sources mention badges from the monastery of Saint Catherine. In Pier's Ploughman's Vision for example, a pilgrim is introduced wearing 'signes of Synay' on his hat. ${ }^{32}$

Of course, Catherine was not just venerated on Mount Sinai. Her popularity spread rapidly. In the eleventh century, a monk of Sinai brought a fragment

30 Adornes, op. cit. (n. 28), p. 227.

3I Adornes, op. cit. (n. 28), p. 227 and Letts, op. cit. (n. 29), p. I42.

32 Charles Roach Smith, 'On pilgrims' signes and leaden tokens', in: Journal of the British Archaeological Association, I (I846), pp. 20I-2, Paul Perdrizet, 'De la Véronique et de Sainte Véronique', in: Seminarium Kondakovianum (Recueil d'Etudes. Archéologie, histoire de l'art, études byzantines, 5; Prague 1932), pp. I-I5 (p. 5), and Robert W. Lightbown, Mediaeval European Jewellery with a catalogue of the collection in the Victoria \& Albert Museum (London 1992), p. 194. Dee Dyas read 'signes of Syse' meaning Assisi. Dee Dyas, Pilgrimage in medieval English literature (Cambridge 200I), p. I55. 
of the relics to Rouen as a gift to the duke of Normandy. ${ }^{33}$ The sanctuary there eventually took the name of the saint: the convent of Sainte-Catherine-duMont. Situated on a hill, the design undoubtedly referred to Mount Sinai. Another famous pilgrimage site was Sainte-Catherine-de-Fierbois (near Tours). Pilgrims came flocking in 1375 when a man was miraculously cured after being paralyzed for seven years. Naturally, this incident gave rise to other marvels. The miracle book of the cult site describes over two hundred miraculous stories that happened at Fierbois through the intercession of Saint Catherine.

The saint was often called upon for help during battle and invoked by prisoners, probably because of her most important attribute: the sword. Philip of Artois went to Mount Sinai after his emprisonment in Cairo to thank Catherine for his release. Philip the Bold (d. I404) visited Fierbois to thank Catherine after his victory at the Flemish town of Westrozebeke in I382. Like Mount Sinai, Fierbois was popular with knights and other people of high social standing, as Saint Catherine was thought to be of a noble family. In I450, Isabelle of Portugal, duchess of Burgundy, ordered an expensive golden badge of SainteCatherine-de-Fierbois, of twenty five sols. ${ }^{34}$ Also René of Anjou, Yolande of Aragon's son, visited Saint Catherine of Fierbois, probably more than once. On 20 July I45I, he bought a number of gold and silver badges from Jehan Juliot, a goldsmith in Sainte-Catherine, at a price of ten livres. ${ }^{35}$ René bought three large gold badges for himself, his wife and their daughter Yolande, six small ones for his chamberlains, a silver 'burlette' - that is a small pendant with the Life of Saint Catherine. On top of this, he bought two dozen large silver badges to give the gentlemen and ladies of the household and four dozen small ones to give to the officers.

The owner of the Belles Heures could have been one of the visitors of Fierbois, so popular with the French nobility. However, pilgrimage sites of Catherine were manifold. Even though a badge of Catherine - from Mount Sinai, SainteCatherine-du-Mont or Sainte-Catherine-de-Fierbois or some other cult of Catherine - would seem an appropriate addition to the manuscript, the images in the Belles Heures are unrecognizable. The badges cannot be attributed to a specific pilgrimage site. Any badge would have been appropriate, because of the association of the miniatures with pilgrims and pilgrimage.

33 Jacobus de Voragine, op. cit. (n. 24), p. 339, Denis Bruna, Enseignes de pelerinage et enseignes profanes (Paris 1996), Pp. I23-4 and Katherine J. Lewis, 'Pilgrimage and the Cult of St. Katherine of Alexandria in Late Medieval England', in: Pilgrimage Explored, ed. J. Stopford (York 1999) pp. 146-8.

34 Comte De Laborde, op. cit. (n. I2), vol. 3: 3, p. 354, no. 6737.

35 Arnaud D'Agnel, Comptes du roi René, vol. I (Paris I9IO), p. 286. 


\section{Traces of Devotion}

In the Grandes Heures as in the Belles Heures, the owner chose a miniature to add the badges to. In both cases, the miniatures are devotional images rather than illustrations of a text, they were incentives for contemplation. The miniature of the Apocalyptic Virgin in the Grandes Heures is a single-leaf image. The smudges and discolorations left by touch indicate its value as an instrument for contemplation. The image does not just illustrate the text at hand. On the contrary, the prayer texts were written to accompany the precious image of the Virgin. The miniature cycle in the Belles Heures on the other hand serves as an incentive for the contemplative thoughts on the Life and Passion of Saint Catherine. Here also, the text supports the image, not the other way around.

With the addition of the badges, the owners elaborated on the iconography and accentuated elements of own choice to give the book a personal slant. In the Grandes Heures, the devotee introduced a community of saints around the image of the Madonna, creating a vision of Paradise. In the Belles Heures, the owner-pilgrim elaborated and expanded on the element of pilgrimage that is firmly embedded in the picture cycle of Saint Catherine. The miniatures give the devout reader the opportunity to follow in Catherine's footsteps and contemplate the events of her life and death, not unlike a pilgrim visiting the sites where Catherine lived and had died. Reflecting the exemplary journey of the pilgrims in the final miniature, the owner of the Belles Heures added the memory of an individual pilgrimage, adding a private and individual chapter to the book. In a way, the owner joined the travellers in the miniature of the Limbourg brothers.

Many things remain uncertain about the whereabouts and users of the Belles Heures (as well as the Grandes Heures for that matter) and many things are left to guesswork: the identity of the person who added the badges (possibly a member of a French noble family), the images on the badges (perhaps Catherine), and, a related problem, the site of pilgrimage where the badges must have originated (Mount Sinai, Sainte-Catherine-du-Mont, Fierbois or another place even?). But even without an identification, the imprints are a fine example of the devotional practice to attach badges to books of hours. The owner used the badges to give a personal twist to the images of the book, so that it fitted his pious intentions even better. The imprints illustrate the purpose of the book as an instrument of devotion rather than a precious object intended solely for admiration. 